\title{
Mali Disiplini Sağlama Yolunda Mali Kural Uygulamaları
}

\author{
Deniz ALÇIN ŞAHINTÜRK*
}

\author{
Öznur AKYOL BULUT**
}

\begin{abstract}
$\ddot{O} Z$
Geçmişten günümüze devletleri ayakta tutan en önemli unsur ekonomileri olmuştur. Ekonomi ise özel ve kamu ekonomisi olarak ikiye ayrlmakta ancak bütünü kamu tarafindan yönetilmekte ve yönlendirilmektedir. Bu yönetme ve yönlendirmenin en önemli aract maliye politikasıdır. Ancak maliye politikasını uygulayan siyasi aktörler kamu hizmetlerini yerine getirirken tıpkı piyasadaki gibi çıkarları doğrultusunda hareket edip, kamu kaynaklarını etkinsiz kullanabilirler. Bu etkinsiz kullanım ise kamu kaynaklarının israf edilmesine ve ekonominin kırılganlı̆̆ının artmasina sebep olmaktadır.

Bu endişelerle ortaya çıkan Kamu Tercihi Ekonomisi ve Anayasal İktisat siyasi aktörlerin bu davranışlarının sınırlanması için mali kural uygulanmasını önermişlerdir. Mali kurallar iradi maliye politikası uygulamalarına getirilen sayısal ve prosedür ile ilgili kısıtlamalardır.

Çalışma kapsamında ilk olarak mali kurallar hakkında teorik bilgi verilmiştir. Daha sonra dünya uygulamaları incelenmiş, dünya uygulamaları çerçevesinde ülkemizdeki mevcut mali kural uygulamaları ve girişimleri analiz edilmiş ve ülkemiz için politika önerilerinde bulunulmuştur.
\end{abstract}

Anahtar Kelimeler: Mali kural, maliye politikası, bütçe, borç, faiz dışı fazla.

Jel Sinıflandirmasi: H3O, H6O, H63, H7O.

\section{Fiscal Rule Practices Towards Fiscal Discipline}

\begin{abstract}
The most important factor that kept the government alive was their economies from the past to the present day. The economy is divided into two as private and public economy, but the whole is managed and directed by the public. The most important tool for this managing and directing is fiscal policy. However, the political actors who implement fiscal policy may act in line with their interests and use public resources ineffective while offering public services.

This inefficient use also causes wasting of public resources and increasing the fragility of the economy. The Public Choice Economy and Constitutional Economics, which emerged with these concerns, proposed the application of fiscal rules to limit these behaviors of political actors. Fiscal rules are numerical and procedural restrictions imposed on voluntary fiscal policy practices.

Theoretical information about fiscal rules is first given within the scope of this study. Then, various practices around the world were examined, current fiscal rule practices and initiatives within this framework of various practices were analyzed and some policy recommendations.
\end{abstract}

Keywords: Fiscal rule, fiscal policy, budget, primary surplus

Jel Classification: H3O, H6O, H63, H7O.

\section{GIRIŞ}

1929 Buhranı kendi koşulları içinde Keynesyen İktisat Teorisini doğurmuştur. Durgunluğun sebebinin talep yetersizliği olduğunu belirtmiş ve

\footnotetext{
* Manisa Celal Bayar Üniversitesi, İ̈BF, Maliye Bölümü, Arş. Gör., deniz.alcin@cbu.edu.tr

** Manisa Celal Bayar Üniversitesi, İ̈BF, Maliye Bölümü, Arş. Gör., oznur.akyol@cbu.edu.tr 
devletin müdahaleci politikalarla talep yaratması gereği üzerinde durmuştur. Talep yaratma endişesiyle kamu açıkları borçlanma ile kapatılmaya başlanmıştır. II. Dünya Savaşı sonunda da yeniden yapılanma politikaları doğrultusunda yine kamu harcamaları arttırılmıştır. Ancak bir süre sonra çoğu ülkede artan kamu borç stoku ve bütçe açıkları büyük bir problem haline gelmiştir. Devletin imkânlarını siyasi ihtirasları doğrultusunda kullanan politikacıların basiretsiz ekonomik davranışları da bunların üzerine gelince Anayasal İktisat Düşüncesi artık "Ekonominin Anayasası" yapılarak devletin bütçeye ve borçlanmaya ilişkin davranışlarına bir kısıtlanma getirilmesi gerektiğini öne sürmüştür.

Çalışmamızın konusunu oluşturan "Mali Kurallar" bu düşüncenin bir ürünüdür. Örtülü olarak aslında uzun yıllardan beri tüm dünya genelinde uygulanan söz konusu kurallar yaklaşık son otuz yıldır yukarıda anlatılan gelişmelerden ötürü birçok ülkede anayasa ve yasalarda yerini almış, özellikle küresel krizden sonra tekrar gündeme oturmuştur.

$\mathrm{Bu}$ doğrultuda çalışmada; ilk önce mali kuralların oluşumuna yol açan gelişmeler kronolojik sıra ile ele alınacaktır. Daha sonraki kısımda mali kurallar detaylı olarak incelenecektir. Akabinde bazı ülkelerde uygulanan mali kurallar üzerinde durularak konuyla ilgili Türkiye'deki gelişmeler ele alınacaktır.

\section{MALI KURALLARA İLIŞKIN TEORIKK ALTYAPI}

Çalışmanın bu bölümünde mali kuralların temelini oluşturan iktisat okulları hakkında bilgi verilip, kuralların özellikleri açıklanacaktır. Sonrasında ise uygulamanın tarihsel gelişimi ve mali kural türleri hakkında bilgi verilecektir.

\section{A. Kamu Tercihi Teorisi ve Anayasal İktisat}

Keynesyen politikaların sonucunda dünya genelinde artan kamu açıkları, borç stokları ve politik alandaki aktörlerin tıpkı piyasada olduğu gibi kendi çıkarlarının peşinde koşması devletin ekonomideki payını fazlası ile büyütmüş, devlet artık "Leviathan" adı verilen bir deniz canavarına benzetilmeye başlanmıştır. $\mathrm{Bu}$ gelişmeler sonucunda devletin başarısızlıkları konuşulmaya başlanmış, bu konu ile ilgili birçok analiz ve çözüm önerisi getirilmiştir. Bunlardan biri James Buchanan'ın öncülük ettiği Kamu Tercihi Teorisidir. Kamu tercihi teorisi, politik süreçte alınan karar ve uygulamaları iktisat biliminin kullandığı araç, method ve varsayımlara dayalı olarak açıklayan bir disiplindir (http://www.canaktan.org/ ekonomi/anayasal_iktisat/kamu-tercihi.htm.) Teorinin temelleri 18. yüzyıla kadar uzanmakla birlikte asıl olarak 1950'li yıllarda üzerinde yoğun çalışmalar yapılmıştır. Teori üç temel varsayım üzerine kurulmuştur. Bunlar; metodolojik bireycilik, homo economicus ve politik mübadeledir. Metodolojik bireyciliğe göre, piyasada mal ve hizmetlere talep oluşturan bireyin tercih mantığı ile siyasal süreçte aday ve parti seçen bireyin tercih mantığı arasında davranış yönünden herhangi bir fark yoktur (Çelebi, 2015:102). Homo economicus varsayımına göre ise her kişi faydasını maksimize edecek şekilde davranmaktadır. Bu durum siyasal karar alma mekanizmasında da böyledir. Politikacılar, seçmenler, bürokratlar gibi siyasal alandaki her bir aktör kendi çıkarını maksimize etmeye çalışırlar. Siyasal süreçte bireyler kendi çıkarlarını maksimize ederken ortaya karmaşık bir siyasal mübadele durumu çıar. Çünkü 
bireyler ilk olarak devletin kurulması noktasında anlaşma yaptıktan sonra, bir de kurulan devletin yapacağ kamu faaliyetleri ile ilgili bir seçim ve anlaşma yapmak zorunda kalmaktadırlar (Çelebi, 2015:102).

Teori pozitif ve normatif kamu tercihi olmak üzere ikiye ayrılmaktadır. Pozitif kamu tercihi, politik karar alma sürecinde gerçekleşen seçmen, politikacı, bürokrat ve çıkar gruplarının davranışlarını analiz etmektedir. Buna göre siyasal karar alma sürecinde siyasal arz cephesinden kaynaklanan sorunlar; politikacıların oy maksimizasyon çabaları, politikada tam rekabetin geçerli olmaması, politik dışsal ekonomiler, politik negatif ölçek ekonomileri, bürokratların bütçe maksimizasyon çabaları, politik miyopluk, hizmet kayırmacılığı, kamusal güç ve yetki dağılımında dengesizlik, şeffaflığın olmaması, gereksiz ve aşırı harcamalardir (Aktan, 2003:87-91). Siyasal talep cephesinden kaynaklanan sorunlar ise; seçmenin eksik enformasyona sahip olması, seçmen ilgisizliği, seçmenin politik miyopluğu, seçmenin siyasal talebini açıklamaması, özel çıkar grupları ve rant kollama sorunlarıdır (Aktan vd., 2006:114-118). Tüm bu sayılan unsurlar "mali yanılma" olgusunu da beraberinde getirmektedir. Hükümet, özellikle başarılı olarak değerlendirildiği dönemlerde kamu harcamalarının faydalarını olduğundan büyük gösteriyor, vatandaşlar üzerindeki vergi yüklerini ise olduğundan az gösteriyorsa vatandaş cephesinde "mali yanılma" ortaya çıkmış demektir (http://www.canaktan.org/ekonomi/anayasal_iktisat/buchananlifelegacy/turkce-kaynaklar/buchanan-pur-maliye.htm). Dolayısıyla aslında devlet başarılı değil başarısız olmuştur.

Normatif kamu tercihi ise siyasal karar alma mekanizmasinda olmas1 gerekeni incelemektedir. Normatif kamu tercihi olması gerekeni araştırırken 1980'li yıllarda "Anayasal İktisat" bu ihtiyacı karşılayacak nitelikte yeni bir disiplin olarak ortaya çıkmıştır. Dolayısı ile Anayasal İktisat teorisi Kamu Tercihi Teorisinin bünyesinde gelişen ayrı bir disiplin durumundadır.

Anayasal iktisat teorisi, devletin bütün yetkilerinin sosyal bir sözleşme niteliğindeki anayasa ile vatandaşlardan aldığını dolayısıyla bu yetkilerin yine vatandaşlar tarafından anayasada sınırlanabileceğini varsaymaktadır. Devletlerin biçimsel temelleri dediğimiz, bir devletin kuruluşunu, örgütlenişini, iktidarın el değiştirmesini ve bireylerin hak ve özgürlüklerini düzenleyen kurallar bütününe “anayasa” denilmektedir (Eker'den aktaran Günay, 2007:127). Anayasalar toplum yaşamını, temel hak ve özgürlükler, siyasal hak ve özgürlükler, sosyal ve ekonomik hak ve özgürlükler ve devletin organları ve işleyiş şekli açısından sınırlandırmaktadır. Tüm bunlara ek olarak, dünya genelinde süregelen ekonomik istikrarsızlıklar sonrası devletin ekonomik davranışlarının da anayasalarda sınırlandırılması gerektiği düşünülmektedir. Böylece bir ekonomik anayasa oluşturulması gerekmektedir. Söz konusu ekonomik anayasanın en önemli kısmı devletin mali politikalarına çerçeve çizen mali kısımdır. Neredeyse bir "mali anayasa" olarak nitelendirilen düzenlemeler ile devletin aşırı büyümesine önlem olarak harcama, vergilendirme ve borçlanma yetkilerine anayasal çerçevede bir sınır çizilmektedir. Yani mali kurallar oluşturulmaktadır. Mali anayasada kilit 
nokta denk bütçedir. Harcama ve vergi sınırlandırmalarıyla denk bir bütçe oluşturulursa devletin borçlanma gereksinimi de azalacaktır.

\section{B. Mali Kural Kavramı ve Özelikleri}

Mali kurallar, devletlerin ekonomik kırılganlıklarını azaltmak amacıyla iradi maliye politikası uygulamalarına getirilen sayısal kısıtlar ve bu kısitların ötesinde yasal ve kurumsal düzenlemeleri kapsamaktadır (Karayazı, 2017:1048).

Mali kural tanımından hareketle mevcut ve önerilen mali kuralların yasal dayanağının anayasa, kanun, politika kuralları veya uluslararası anlaşmalardır (Şen, 2010:28). Kuralların anayasalarda yer almasının avantajı her hükümet döneminde kolaylıkla değiştirilememesidir. Bunun sonucunda halkın gelecek öngörüsünün daha sağlıklı gerçekleşeceği beklenmektedir. Ancak bu durum aynı zamanda ekonomik şoklara kolay ayak uydurulamaması tehlikesini de taşımaktadır. Mali kuralların yasalarda düzenlenmesi anayasalar kadar olmasa bile hükümet için bağlayıcı nitelik taşımaktadır. Kuralların politika kuralı olarak oluşturulması sonucunda ise mali kuralların rahatlıkla terk edilebileceğini söylemek mümkündür.

Mali kuralların uygulamaya yönelik taşıması gereken özellikler ise sürdürülebilirlik, istikrar, basitlik, operasyonel rehberlik, esneklik, izleme ve uygulama kolaylığıdır. Mali kuralların sürdürülebilirlik özelliği, belirlenen sayısal hedeflerin sürdürülebilir olmasını, kuralların istikrarlı olması özelliği, ülkelerin uygulayacağı iradi maliye politikalarının ve otomatik istikrarlandırıcıların uygulanmasına engel olmamasını, kuralların basitlik özelliği kuralların karar vericiler ve halk tarafından kolayca anlaşılmasını, operasyonel rehberlik özelliği, mali kuralın bütçe sürecine rehberlik etmesini, kuralların esneklik özelliği kuralların uzun süre uygulanmasını ve herhangi bir şok durumunda kolayca terk edilmemesini, izleme ve uygulama kolaylığı özelliği ise kurallara uyumun doğrulanmasının kolay olması ve sapmalar durumunda yaptırımların uygulanabilmesini kapsamaktadır (IMF, 2018:2).

\section{Mali Kuralların Tarihsel Gelișimi ve Türleri}

Bilinen en eski mali kural bütçe denkliğidir. Dolayısı ile mali kuralların geçmişi çok eskilere dayanmaktadır. Ancak bir asırdan daha fazla bir süredir mali kurallar yasal temellere oturtulmaya başlanmıştır. $\mathrm{Bu}$ süreci üç dönem halinde ele almak mümkündür. İlk dönemde, bazı federal sistemlerde federe devletler altın kural uygulamasını benimsemişlerdir. Altın kural uygulamasında devletler sadece yatırım harcamaları için borçlanabilmektedir (Honjo, 2007:3). Bu kural ile, bütçe dengesi kuralı, gelecek yıllarda kalkınma ve büyümenin altyapısını oluşturacak yatırım harcamaları için esnetilmiş olmaktadır.

İkinci dönemde, İkinci Dünya Savaşından sonra bazı sanayileşmiş ülkeler (Almanya, İtalya, Japonya, Hollanda) para programlarını içeren istikrar programlarına destek olarak denk bütçe kurallarını getirmişlerdir (Günaydın ve Eser, 2009:53).

Son dönemde ise Yeni Zelanda'nın enflasyon hedeflemesi uygulamasından sonra kabul ettiği "Mali Sorumluluk Kanunu" sonrası birçok ülke, mali kurallar uygulamaya başlamıştır. Bu dönemdeki mevcut kuralların 
ortak paydası hesap verme anlaşmalarını, güncel ve düzenli raporlama zorunluluğunu ve orta vadeli makro bütçe çerçevesini içeren daha fazla şeffaflık standartları ile desteklenmesidir (Şevik, 2008:52). Mali kurallar tüm dünyada ve ülkemizde 1990'lı yıllardan itibaren yoğun ilgi gören ve uygulanan bir olgu haline gelmiştir.

Mali kurallar, türlerine göre; sayısal mali kurallar ve sayısal olmayan (prosedürel) mali kurallar olarak ikiye ayrılmaktadır (Karayazı, 2017:1049).

Sayısal mali kurallar (Debrun'dan aktaran Günaydın ve Eser, 2009:55);

$>$ Denk bütçe kuralları, altın kural ve kamu açıklarına sınır getiren açık kuralları,

$>$ Toplam veya net kamu borcunu sınırlandıran borç kuralları,

$>$ Toplam harcamalar veya harcamaların türlerine göre üst sınır ifade eden harcama kuralları,

> Vergi yükünü ya da bütçedeki gelir artışını sınırlayan kurallardan meydana gelmektedir.

Denk bütçe kuralı genelde katı bir şekilde uygulanmamaktadır. Çünkü konjonktür dönemlerinde bütçe açığı veya fazlası vermek ekonomik istikrar için gerekli olmaktadır. Ayrıca katı bir bütçe dengesi, kalkınma için gerekli olan bazı sosyal ve yatırım harcamalarının yapılmasına engel olabilmektedir. Bu yüzden ülkeler denk bütçe kuralı yerine altın kuralı benimsemektedirler. Ancak eğitim ve sağlı gibi kalkınma carilerinin yatırım harcaması kapsamına alınmayıp sadece inşaat gibi harcama kalemlerinin yatırım kapsamında değerlendirilmesi sürdürülebilir bir büyümenin önünde bir engel oluşturabilir(Özlale, 2010:5). Yine denk bütçe kuralı yerine belli bir bütçe açığını sınır kabul eden mali kural ülkeler için daha uygulanabilir olmaktadır.

Borçlanmaya ilişkin kurallar çerçevesinde, iç ve dış borç stokunun ayrı ayrı ya da birlikte GSYİH' ya oranına anayasa ve yasalarla belli bir sınır getirilmesi, yerel yönetimlerin borçlanma yetkisinin sınırlarının çizilmesi, hazinenin merkez bankasından kısa vadeli avans kullanımının yasalarla yasaklanması ya da bir sınır getirilmesi uygulamalarına gidilebilir (Şengönül ve Songur, 2010:9).

Denk bütçenin sağlanması için özellikle bütçe açığı olan durumlarda ya harcamaların kısılması ya da vergilerin artırılması gerekmektedir. Vergi prosedürü belirli bir vakit gerektirdiğinden ve vatandaşlar vergi artırımına ve yeni vergiler koyulmasına tepki göstereceklerinden, harcamaların düşürülmesi bütçe denkliğinin sağlanması yolunda daha kolaydır. Bu nedenle kamu harcamalarına disiplin getirmek amaciyla kamunun yapacağ 1 toplam harcamanın GSYİH'ya oranının anayasa ve yasalarda belirlenmesi, kamu harcama artışı kararı için meclisin belirli bir çoğunluğunun onayının gerekliliği, kamu harcaması artışının karş1lığının (finansmanının) hemen belirlenmesi ve vergi yükünün aşırı artışını engellemek amacıyla kamu harcaması artışına belirli bir limit konulması, merkezi devletten yerel yönetimlere yapılacak nakit aktarımının sınırlarının yasalarda belirlenmesi (Şengönül ve Songur, 2010: 7-8) önem taşımaktadır. 
Gelire ilişkin kurallar çerçevesinde, vergi konusunun sınırlandırılması, toplam vergi yükünün sınırlandırılması, vergi oran yapısında düzenlemeye gidilmesi ve vergilendirme yetkisinin kısmen yerel yönetimlere devri gibi uygulamalara gidilebilir (Çelebi, 2015:162.). Böylelikle tarafsız vergi uygulaması gerçekleştirilerek verginin piyasa aktörlerinin kararları üzerindeki saptırıcı etkisi ortadan kalkabilir. Böylelikle kazan-kazan kuralı çerçevesinde Laffer'in ortaya attığı gibi kişilerin vergi yükü azaldıkça piyasada çalışma ve üretim artabilir. Bu durum devletin vergi geliri artışını da beraberinde getirecektir.

Mali kurallar ancak bütçelemede yapılacak diğer değişikliklerle desteklendiğinde etkili olabilmektedir. Bu değişiklikler (Şevik. 2008:50);

$>$ Bütçelemenin bir yıldan orta vadeye uzatılması,

$>$ Gelecekteki bütçe koşullarına ilişkin projeksiyonların yapılması,

> Yapılacak politika değişikliklerinin gelecek bütçelere etkisinin tahmin edilmesi,

$>$ Bütçeye ilişkin izleme prosedürlerinin oluşturulması ve böylece gerektiğinde düzeltici tedbirlerin alınması,

$>$ Politikacıların kurallara uymasını temin etmek için zorlayıcı mekanizmalar oluşturulması şeklinde özetlenebilir.

Sözü geçen tüm bu mekanizmalar sayısal olmayan (prosedürel) mali kuralı oluşturmaktadır. Prosedürel mali kurallar sayısal mali kuralların işleyişini destekleyici niteliktedir. Nitekim mali kural uygulayan ülkeler incelendiğinde borç stokunda ve mali yapıda görülen olumlu gelişmeler, sayısal mali kural uygulamalarının yanında mutlaka prosedürel mali kuralların da uygulanması ile elde edilmiştir (Özlale, 2010:4).

Sayısal mali kurallar kapsamında bütçe dengesi ve borç kurallarının büyük kısmı uluslararası anlaşmalarda bulunurken, harcama kuralları genellikle ulusal mevzuatlarda yer almakta, mali kuralların anayasal düzeyde düzenlenmesi ise Fransa, İspanya, Almanya, Polonya ve İsviçre'de uygulanmaktadır (Schaechter vd., 2012:17).

\section{MALI KURAL UYGULAMASINA İLIŞKİN ÜLKE ÖRNEKLERİ}

Özellikle 1980'li yıllardan itibaren küreselleşme olgusu ile birlikte artan dünya ticaret hacmi Ekonomik İşbirliği ve Kalkınma Örgütü (OECD), Dünya Ticaret Örgütü (WTO), Avrupa Birliği (EU), Uluslararas1 Para Fonu (IMF), Dünya Bankası (WB) gibi birçok uluslar üst ü kuruluşların ortaya çıkmasına ve kuruluşların birbirine benzer ortak kuralları hayata geçirmesine neden olmuştur (Güngör, 2016:178-179). Mali kural uygulaması 1990 yılında 7 ülkede başlamış, küresel krizin hemen sonrasında uygulanan ülke sayısı 80'e ulaşmıştır (Sönmez, 2011:21). Ancak her ülke uygulaması ülkelerin siyasi, kurumsal ve ekonomik yapısına göre değişmektedir.

Amerika Birleşik Devletleri (ABD)'nde mali kural niteliğinde uygulamalar aslında çok eskilere dayanmaktadır. Federal düzeyde kurallı maliye politikası uygulaması ilk olarak Birinci Dünya Savaşı sırasında meydana gelen ek finansman ihtiyacına yönelik, hükümetin borçlanma yetkisini kısıtlamak amacıyla 
çıkarılan 24 Nisan 1917 tarihli Tahvil Kanunu ile başlamıştır (Kaya, 2009:52). Ancak 1929 buhranı bir dönüm noktası olmuştur. Buhrandan sonra devletin yeni hizmetler üstlenmesi transfer harcamaları başta olmak üzere tüm harcamaları arttırmıştır. Bunun sonucunda bütçe açıkları ve kamu borcu devasa boyutlara varmıştır. Yine 1970'li yılların ortalarında yaşanan kriz ve yaşanan durgunluk sonucu ekonominin canlandırılması için vergi oranlarının indirilmesiyle devletin gelirleri azalmıştır. Bu durum bütçe açıklarını arttırmıştır. ABD Anayasasında 1980'li yıllara kadar denk bütçeye ilişkin hiçbir kural yer almamıştır. Ancak devlet belli dönemlerde denk bütçenin sağlanması yönünde adımlar atmıştır. 1985 yılında kabul edilen ve kural uygulaması çerçevesinde değerlendirilen başka bir kanun olan Gramm-Rudman-Hollings (GRH) Kanunu ile de kamu açıkları mali yıl bazında sınırlandırılmış, 1986 yılından 1991 yılına kadar denk bütçenin uygulanması amaçlanmıştır (Kaya, 2009:52). Buna göre başkan her mali yıl, kanundaki hedefe uygun şekilde bütçe rakamı teklif edecek ve eğer bütçe uygulanırken bütçe hedeflerine ulaşılamayacağı anlaşılırsa, otomatik olarak zorunlu harcama kesintileri yapılacaktır (Günay, 2007:154). Bu uygulamanın çok başarılı olmadığı gözlemlenmiştir.

Ekonomide yaşanan olumsuzluklar sonucunda ve anayasal iktisat akımının etkisiyle 1990'lı yıllardan itibaren tekrar mali kural uygulamalarına başlanmıştır. Bu durum tablo 1'de de yasal uygulamasıyla gösterilmektedir. Bu bağlamda, parlamentodaki görüşmelerde herhangi bir harcama kaleminde artış isteniyorsa başka harcama kaleminde kesintiye gidilecektir. Harcama kararları ve kesintileri harcamaların ihtiyari olup olmadığına göre kesinleşecektir. ABD kamu mali sinıflandırmasında ihtiyari harcamalar, savunma-güvenlik, ulusal ve uluslararası harcamalar toplamından oluşurken ihtiyari olmayan harcamalar ise sosyal güvenlik, sağlık, sosyal yardım, emeklilik ve özürlü bakım hizmetleri gibi harcamaların toplamından oluşmaktadır (Kaya, 2009:54). Bu kapsamda, 1990 yılında 1991-1993 dönemi için üç alanda savunma, uluslararası ve savunma hariç ulusal harcamalar için ayrı ayrı tavanlar belirlenmiş iken 1994-1995 yıllarında ihtiyari harcamaların tümü için tek bir tavan tespit edilmiştir (Şen, 2010:38). 1997 yılı bütçe uygulama kanunu kapsamında ihtiyari harcama kalemi üst sınırları, savunma ve savunma dışı harcama kalemi üst sınırları ayrı ayrı belirlenmiştir (Şen, 2010:38). Sonuç olarak 1990 sonrasında, kamu kesimi ortalamada faiz dışı fazla vermiş, kamu açı̆̆ı iyileşmiş, borçlanma azalmıştır. Ancak borçlanma göstergeleri 2001 y1lından sonra tekrar bozulmuştur. Günümüzde birçok eyalette bütçe gelir ve harcamalarına ilişkin kararlar meclisin nitelikli çoğunluğu ile alınabilmektedir. 2009 y1l itibariyle federal devlette otuz eyalet, vergi ve harcama miktarlarını kurala bağlamış, bu eyaletlerden 17 tanesi bu söz konusu kuralları anayasal düzeyde, 13'ü ise yasal düzeyde düzenlemiştir (Sakal ve Şahin, 2009:95).

Borçlanma konusunda ise beş eyalette herhangi bir anayasal düzeyde mali kural uygulanmamakta, 19 eyalette borçlanma yetkisinin kullanımı için referanduma gidilmesi gerekmekte, 12 eyalette ise borçlanma yetkisinin kullanımı için nitelikli çoğunluk kararı gerekmektedir (Sakal ve Şahin, 2009:98). 
AB'de ise mali alanda birden çok karar alıcının bulunmasının mali disiplini ve ortak para biriminin istikrarını zayıflatabileceği düşüncesi ile mali kurallar benimsenmiştir (Şen, 2010:35).

AB'ye üye ülkelerde Maastricht Anlaşması ile İstikrar ve Büyüme Paktı çerçevesinde oluşturulan ortak mali kurallar uygulanmaktadır. Maastricht Kriterleri uluslar üstü nitelikte mali kurallardır. Maastricht Anlaşması bir anlamda Robert Mundell'in Optimum Para Sahası Kuramının uygulamaya geçirilmesidir. $\mathrm{Bu}$ kuram, belli bir grup ülkenin ulusal para birimlerinin değerini, belirlenen kurlar üzerinden birbirlerine sabitlemesi ve üye ülkelerin para birimlerinin değerinin birliğe üye olmayan ülkelerin para birimleri karşısında serbest dalgalanmasını ifade etmektedir (Ata ve Silahşör'den aktaran Utkulu, 2005:3). Bir para sahasının optimum para sahası olması için belli başı özelliklere sahip olmas1 gerekir. Bu özellikler (Samsar, 2003:1);

- Ülkelerin enflasyon oranlarındaki benzerlikler,

- Ülkeler arası yüksek faktör hareketliliği,

- Ülkelerin ekonomik açıklıkları,

- Ekonomilerin büyüklükleri,

- Mal çeşitlendirme derecesi,

- Fiyat ve ücret esnekliği,

- Mal piyasasi entegrasyon derecesi ve mali entagrasyondur. 


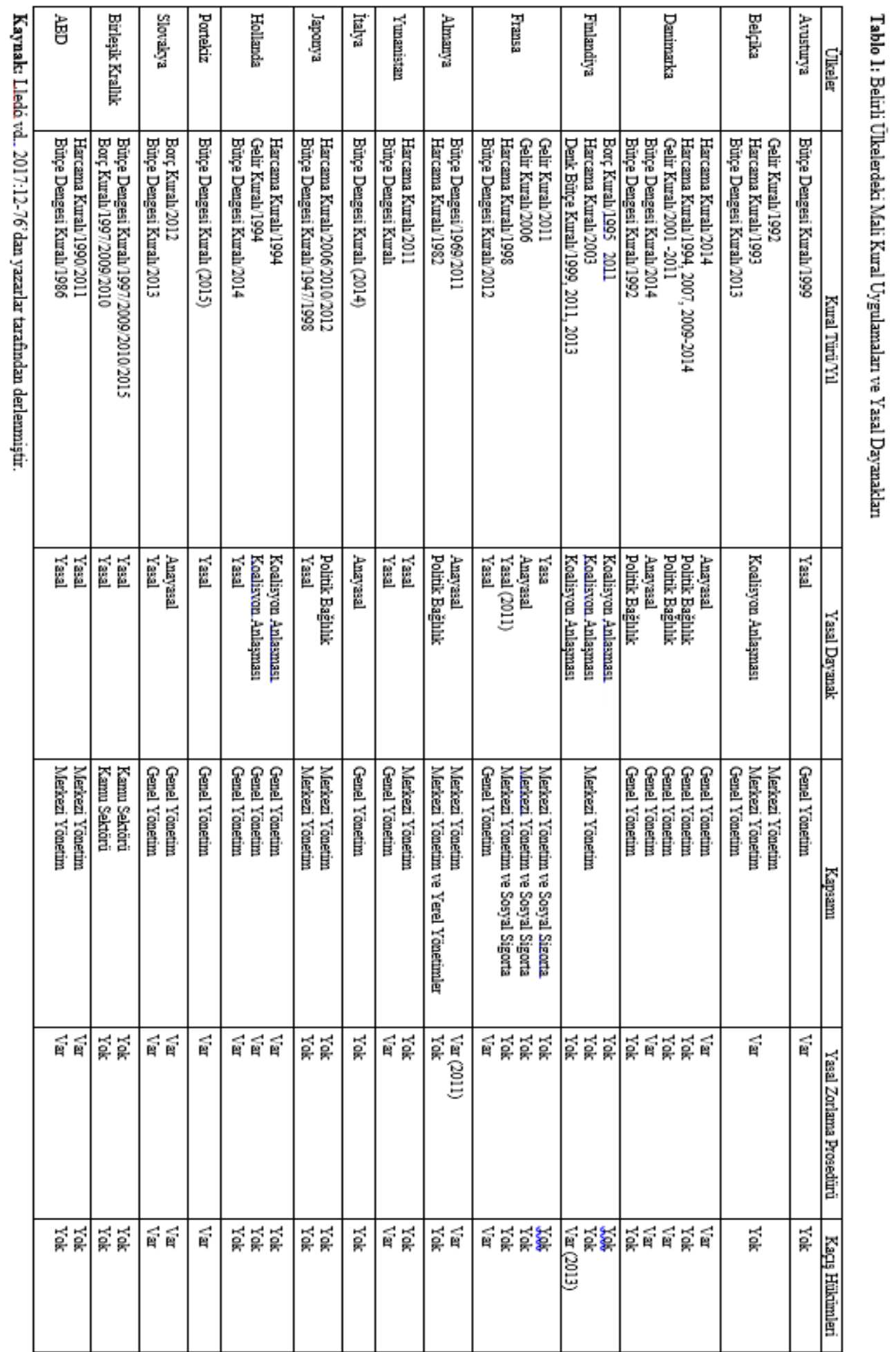


Maastricth anlaşması bu şartların sağlanması için AB'de belirli ekonomik kriterler belirlemiştir. Maastricht Anlaşması ile belirlenen kriterlerden özellikle ulusal bütçe açıklarının Gayrisafi Yurtiçi Hâsıla'nın (GSYIH) yüzde 3'ünden fazla olmamas1, kamu borcunun GSYİH'nın yüzde 60'ını geçmemesi kriterleri şu an üzerinde durulan en önemli mali kurallardır. Diğer kriterler ise herhangi bir ülkenin yıllık ortalama enflasyon oranının, bir önceki yılda $A B$ 'nde en düşük enflasyon oranına sahip üç üye ülkenin enflasyon ortalamasının en fazla 1.5 puan üstünde olması, uzun vadeli faiz oranlarının, birlikteki en düşük enflasyona sahip 3 ülkenin faiz oranları ortalamasını en fazla 2 puan aşabilmesi, parasının, son 2 yıl itibarıyla diğer bir üye ülke parası karşısında devalüe edilmemiş olması kriterleridir (Sevgi, 2018:178). Maastricht Anlaşmas1 yukarıda belirtilen kriterlerden ciddi durgunluk dönemlerinde ya da olağanüstü koşullarda, belirli sınırlar içinde sapılabileceğini de belirtmiştir. Kaçış hükümleri olarak da adlandırılan bu istisnaların kesin kuralları belirlenmediği takdirde keyfi uygulamaların gündeme gelmesi de söz konusudur (Miynat ve Bostan, 2015:536). $\mathrm{Bu}$ durum mali kural uygulamasının ruhuna aykırılık taşımaktadır. Ayrıca AB'de Maastricht kriterlerinin uygulanmasını denetlemek ve anlaşmaya güç katmak için İstikrar ve Büyüme Paktı (İBP) yürürlüğe konulmuştur. Paktaki önleyici kurallar çerçevesinde, aşırı açıkların oluşmasından kaçınmak için Avrupa Konseyi üye ülkelerin orta vadeli bütçe hedeflerinden ciddi bir şekilde saptığını ya da sapma eğiliminde olduğunu tespit ettiğinde erken uyarı yayımlamaktadır (Şen, 2010:35). Yine İBP düzeltici kurallar adı altında üye ülkenin GSYH' nin yüzde 3'ü şeklinde belirlenmiş açık sınırını geçmesi halinde aşırı açı prosedürü işlemeye başlamaktadır. $\mathrm{Bu}$ prosedürde açığın makul nedenlerle ortaya çıkıp çıkmadığ araştırılmaktadır. Eğer makul bir nedenle söz konusu açık oluşmamışsa konsey "tavsiye kararı" almaktadır. Ancak, tüm bu mekanizmalar yeterli bir yaptırım gücü oluşturmamaktadır. Güçlü yasal temellere dayanan ve sıkı bir uygulamaya tabi olan bütçe dengesi ve borç kuralları daha iyi bütçe sonuçlarına katkıda bulunmuştur (IMF, 2009:15) Ancak yine de Almanya, Fransa, Hollanda, Yunanistan 2000'li yılların başlarında aşırı açık sınırını geçmişlerdir. Mart 2005'te, Avrupa Konseyi, kalıcı hükümet açıkları ve Aşırı Açık Prosedürü tarafindan belirlenen eşikleri aşan borçlar için mazeretler listesi kabul etmiştir (Hagen, 2005:7).

Tablo 1'den de görüldüğü üzere AB'de yer alan belirli ülkeler Maastricht kriterlerini baz alarak ağırlıklı olarak yasal düzenlemelerle kendi mali kurallarını oluşturmuşlardır. $\mathrm{Bu}$ düzenlemeler çoğunlukla harcama ve bütçe kriterlerinden oluşmakta ve Almanya haricinde 1990'lı ve 2000'li y1llarda uygulanmaya başlamaktadır. Tablodaki ülkeler arasında mali kural uygulamasını bütçe kuralı ile 1969 yılında ilk gerçekleştiren ve anayasal hüküm altına alan Almanya olmuştur.

Japonya'da kamu mali yönetimini düzenleyen temel kanunlar; 1946 tarihli Japon Anayasası, Tablo1'de de görüldüğü üzere 1947 tarihli Kamu Maliyesi Kanunu ve yine 1947 tarihli Parlamento Kanunudur. Hala yürürlükte olan Kamu Maliyesi Kanunu'nda bir altın kural maddesi mevcuttur. Buna göre 
hükümet yalnızca kamu altyap1 hizmetlerinin yerine getirilmesi amaciyla borçlanabilecektir. Ancak bu kural daha sonra esnetilmiş cari harcamalar için de borçlanma yetkisi alınmıştır (Kaya, 2009:59). Bu durum ülkenin borç stokunu önemli ölçüde arttırmıştır.

1981 y1lında Mali Konsolidasyon Anlaşması yürürlüğe konulmuştur. Bu anlaşmanın amacı, 1970'lerde hızla artan Japonya'nın devlet borçlarını azaltmaktır. Buna göre 1982 yılında bütçe taleplerinde yüzde 0 artış, 1983 y1lında yüzde 5 azalma ve yatırım harcamalarında yüzde 0 artış, 1984 yılında ise cari harcamalarda yüzde 10 azalış ve yatırım harcamalarında yüzde 5 düşüş hedeflenmiştir (Hagen, 2005:31). Ancak belirlenen sınırlamalar ek bütçe uygulamalarında dikkate alınmadığı için ek bütçe yapılarak yine harcama artışı sağlanmıştır (Şen, 2010:39) 1990 yılına kadar Japonya'nın borç oranı ekonomik büyümenin etkisiyle düşmüştür (Hagen, 2005:7). 1990'l1 yıllarda da özellikle cari harcama limitlerinde azalma hedefi devam etmiş, sadece yatırım harcamaları ve özel programlar için ek fon ayrılmasına karar verilmiştir (Hagen, 2005:31). Ancak kabarckk ekonomisinin etkisi ile başlayan durgunluk 1990'l1 yıllarda ekonomik göstergelerin kötüleşmesine neden olmuştur ve bu durum uzun süre devam etmiştir.

Tüm bu gelişmelerin sonucunda 1990'lı yılların ortalarında Mali Yapısal Reform Yasası oluşturulmuştur. Yasayla belirlenen hedefler uyarınca; altın kural 2003 yılına kadar yeniden işler hale getirilecek ve cari harcamalar için devlet iç borçlanma senedi ihracı uygulaması sona erdirilecek, sosyal güvenlik sistemi hariç genel devlet açıklarının GSYH içerisindeki payı 2003 yılına kadar yüzde 3 düzeyine düşürülecek ve 2003 yılından sonra vergiler, sosyal güvenlik katkıları ve açık toplamının GSYH içerisindeki payı yüzde 50 eşik değerini aşmayacaktır (Kaya, 2009:61). Ancak ülkede yaşanan durgunluk bu kuralların uygulanmasına imkân vermemiştir. Ocak 2002'de Bakanlar Kurulu 2002 mali yılında yeni devlet tahvili konusunu 30 trilyon Yen ile sınırlayan ve 2010 yılı başında faiz dışı fazlalara ulaşılması gerektiğine karar veren "Yapısal Reform ve Orta Vadeli Ekonomik ve Mali Bakış Açısını" kabul etmiştir (Hagen, 2005:43). Ancak hedefler durgunluğun devam etmesi nedeni ile tutturulamamıştır. Devlet iç borçlanma enstrümanlarının hızla yaygınlaşması sonucunda, genel devlet brüt borç stokunun GSYH içerisindeki pay1 1980 y1lındaki yüzde 52,1 düzeyinden, 2007 y1lına gelindiğinde yüzde 194,4 düzeyine yükselmiştir (Kaya, 2009:60). 2010 yılında yürürlüğe giren ve pay as you go uygulamasını içeren "Mali Yönetim Stratejisi" ise her harcamanın gelir olarak mutlaka bir karşılığ1 olmas1 gerektiğini ifade etmektedir (Schaechter vd., 2012:43).

Küresel kriz sonrası dünya genelinde mali kurallar tekrar gündeme gelmiştir, çünkü ABD'de başlayan kriz ekonomik altyapısı güçsüz olan birçok ülkeyi etkilemiş, ülkelerin ekonomisi küçülmüss, buna bağlı olarak dünya ticaret hacmi azalmıştır. Krizden en fazla etkilenen ülkelerin başında gelen İngiltere 2012 yılında ardı ardına iki kere küçülerek "çift dipli resesyon" yaşamıştır (Şen ve Kaya, 2015:58). Kriz kapsamında birçok ülkede para ve maliye politikas1 çerçevesinde önlem alınmıştır. ABD, Eylül 2008'de yaklaşık 800 milyar dolarlık 
bir kurtarma paketi ile piyasaya müdahale etmiştir. Para politikası kapsamında ABD Merkez Bankası (FED), açık piyasa işlemleri, vadeli ihale kolaylığı, vadeli menkul kıymet borç verme kolaylığı ve piyasa yapıcılığ 1 kredi kolaylığı gibi işlemlerle piyasadaki para hacmini arttırmıştır (Karayazı, 2017:1051). Ancak para politikası kriz ile mücadelede yetersiz kalmıştır. Maliye politikası kapsamında ise birçok ülkede göze çarpan ilk uygulama talebi arttırıcı nitelikte olan vergi indirimleridir. Vergi indirimleri hem dolaylı hem dolaysız vergilerde yapılmış, böylece piyasa aktörlerinin tümünü kapsamıştır. $\mathrm{Bu}$ uygulama ile ekonominin hem arz hem talep tarafının iyileştirilmesi hedeflenmiştir. Ayrıca kamu harcamalarının ağırlığı da değișmiş, sosyal hizmetler ve kamusal faydaya yönelik kamu hizmetleri azalmıştır (Sönmez, 2011:22). Telafi edici nitelikteki maliye politikaları sonucunda birçok ülkede bütçe açığı ve devlet borçları artmıştır. Sonuç olarak, söz konusu genişletici maliye politikası uygulamaları mali kural uygulamalarından sapmaları da beraberinde getirmiştir. Ortaya çıkan bu durum sonucunda birçok ülkede mali kural uygulamaları kaldırılmış ya da tekrar gözden geçirilmiştir. Örneğin, İspanya 2010 yılında bütçe açığını azaltmayı hedeflediğinde ilk olarak kamu yatırım harcamalarını azaltmayı tercih etmiştir (Creel ve Saraceno, 2010:108). Küresel krizden hemen sonra 2009 yılı itibariyle içinde ağırlıklı olarak $\mathrm{AB}$ ülkelerinin bulunduğu 31 ülkede mali kural uygulamalarında bir değişikliğe gidilmeme kararı alınmış, 25 ülkede mali kural uygulamalarının kriz ile tutarlı olmadığı ortaya çıkmış ancak değişikliğe gidilmemiş, aralarında Avusturya, Finlandiya, Almanya, Hollanda ve İngiltere'nin olduğu 16 ülkede ise ya kurallar değişmiş ya da uygulama kaldırılmıştır (IMF, 2009:35). Ancak daha sonraki yıllarda birçok ülkede mali kural revize edilmiş ya da yeni mali kurallar uygulamaya başlamıştır. Örneğin; Bulgaristan harcama kuralının uygulanmasına ara verip, denk bütçe ve fazla hedeflerini 2012 yılında revize etmiş, Finlandiya'da borçları düşürme kuralı 2011 yılında tekrar uygulanmaya başlamış, İngiltere bütçe ve borç kuralını tekrar uygulamaya başlamış, Almanya harcama artış hızına yıllık yüzde 1'lik sınır getirilen kuralı 2010-2011 yıllarında uygulamamış, Avusturya bütçe kuralına ilişkin hedeflerini 2011 yılında revize etmiş, Polonya ve ABD 2011 yılında harcama kuralı uygulamaya başlamışıır (Karayazı, 2017:1055). Kaldı ki İstikrar ve Büyüme Paktı hükümlerinde de küresel krizden sonra belirli yıllarda değişiklik yapılmıştır. Bunlar; 2011 yılında "Altılı Paket", 2013 yılında "Mali S1kılaştırma ve İkili Paket", 2014 yılında "IBPP Gözden Geçirme" ve 2015 y1lında "IBP Esneklik" revizyonlarıdır. Altılı Paket uygulaması çerçevesinde AB'nin ekonomik yönetim kurallarının büyük ölçüde iyileştirilmesiyle Pakt daha kapsamlı ve öngörülebilir hale getirilmiş, hükümetler arası bir anlaşmanın parçası olan İstikrar, Koordinasyon ve Yönetişim Antlaşması'nın bir parçası olan mali sıkılaştırma ile orta vadeli hedeflerle belirlenen bütçe hedeflerinin önemi güçlendirilmiş, üye devletler arasındaki ekonomik koordinasyonu güçlendiren ve ikili paket olarak adlandırılan kanunlarla İBP'na bağlılık arttırılmış, daha sonra ikili ve altılı paket düzenlemeleri tekrar gözden geçirilmiş ve en son İBP esneklik revizyonları ile yapısal reformlar, yatırım ve mali sorumluluk arasındaki bağın güçlendirilmesi 
amaçlanmıştır (https://ec.europa.eu/info/business-economy euro/economic-andfiscal-policy-coordination/eu-economic-governance monitoring-preventioncorrection/stability-and-growth-pact/history-stability-and-growth-pact_en\#2014).

\section{III. ÜLKEMIZDE UYGULANAN MALİ KURALLAR}

Mali kural, ekonomide maliye politikası amaçlarından biri olan mali istikrarı gerçekleştirebilmek için uygulamaya konulan iktisat politikası uygulamaları arasında yer almaktadır. Dünya uygulamalarına benzer şekilde Türkiye'de ismi mali kural olarak belirtilmese de özellikle 1990'lı yıllardan itibaren zaman zaman mali kural niteliğinde uygulamalara rastlamak mümkündür.

Özellikle 1994 yılında yaşanan krizin devamında uygulanan maliye politikalarında, kamu borçlarının sürdürülebilir hale gelmesi için faiz dışı denge ön planda tutulmuş ve kamunun borçlanmasına yönelik sınır getirilmesi konusundaki fikirler önem kazanmıştır. 2000 yılı sonrasında bu politikaya yönelik bazı düzenlemeler de yapılmıştır (Dede, 2010:91).

1990’l1 yıllar Türkiye'si ekonomik olarak hayli güçsüz bir yapıya sahiptir. $\mathrm{Bu}$ güçsüzlük sebebiyle borçlanmada karşılaşılan en önemli riskte yüksek faizli borçlanma olarak karşımıza çıkmıştır. Yüksek faizli borçlanmanın sonucu borçlar yönetilemez hale gelmiştir. Tüm bunlara ek olarak, Türkiye'de harcamaların bütçe dışına çıkartılması bütçenin şeffaflığını zedelemiş, yolsuzluk ve israf artmış, bu durum mali disiplinden uzaklaşılmasına ve iç borç dinamiklerinin çı̆̆ gibi büyümesine neden olmuştur (Binay, 2003:258). Bu yüzden 1990'l1 yıllardan itibaren borçlanmayı azaltmak için faiz dışı fazla verme, özelleştirme geliri elde etme ve hazine borçlanması ve garanti verilmesini kısıtlama yoluna gidilmiştir.

Bütçe dışı fonların ve bütçeden karşılanmayan harcamaların yarattığ belirsizlik ortamını engelleyebilmek ve mali disiplini ve bütçe birliğini güçlendirebilmek amacıyla, 1992 yılında bütçe kanunu ile fonların her türlü gelirlerinin Merkez Bankasında açılan "Müşterek Fon Hesabına" yatırılması uygulaması başlatılmış, bu kapsamda 63 adet bütçe dışında yer alan fon bütçe kapsamına alınmıştır (Dede, 2010:97).

Bu süreçte uygulanan faiz dışı fazla, üzerinde önemle durulması gereken mali kural uygulamasıdır. Bu mali kural literatürde dünya uygulamalarından farklı olarak bir yasal düzenlemeye dayanmadığ 1 için örtük mali kural adlandırılmaktadır (Büyükkaya, 2010:11). Faiz dış1 fazla, kamunun gelirlerinden faiz dışı harcamalar çıkartıldıktan sonra arta kalan tutarın sürekli yükseltilmesi gereğini amaçlamakta, bu amacin gerçekleştirilmesi sonucunda kamu borç stoku azaltılabilmektedir. Bu hedef aynı zamanda o dönem IMF niyet mektuplarında da belirtilen hedef olmuştur. 2000 krizinden sonra uygulamaya konan istikrar programında mali kural kavramı kullanılmamıştır. Fakat, Avrupa Ekonomik ve Parasal Birliği üyeliği için sağlanması şart olan Maastrich Kriterleri çerçevesinde Borç Yönetimi Açısından AB'ye Uyum Kriterleri adı altında gerekli sınırlamalar oluşturulmuştur.

2000 ve 2001 krizinden sonra Güçlü Ekonomiye Geçiş Program1 çerçevesinde mali dengenin sağlanmasına yönelik uygulanan harcama politikaları; kamu kesiminde çalışanların ücret ve maaş artışlarının enflasyon oranına 
endekslenmesi, kamu kurumlarına bütçeden yapılan aktarımların sınırlanması, kuruluşların saydamlığını ve hesap verebilirliğini arttırmak amacıyla 5018 sayılı kanunun temelini oluşturan stratejik planlama ve performans esaslı bütçeleme çalışmalarına ağırlık verilmiştir (Dede, 2010:103).

Atılan bu adımlar neticesinde ekonomi 2002-2008 y1lları arasında toparlanmış, tablo 1'den görüleceği üzere Türkiye, Maastricht Kriterleri'nin bütçe kriterini 2005-2008 y1lları arasında tutturmuştur.

Tablo 2: Türkiye'nin 2000-2008 Y1llar Arası Bütçe Dengesi Göstergeleri (GSYİH'ye Oran1)

\begin{tabular}{|l|l|l|l|l|l|l|l|l|l|}
\cline { 2 - 9 } \multicolumn{1}{c|}{} & $\mathbf{2 0 0 0}$ & $\mathbf{2 0 0 1}$ & $\mathbf{2 0 0 2}$ & $\mathbf{2 0 0 3}$ & $\mathbf{2 0 0 4}$ & $\mathbf{2 0 0 5}$ & $\mathbf{2 0 0 6}$ & $\mathbf{2 0 0 7}$ & $\mathbf{2 0 0 8}$ \\
\hline $\begin{array}{l}\text { Merkezi } \\
\text { Yönetim } \\
\text { Bütçe } \\
\text { Giderleri }\end{array}$ & 30,1 & 35,4 & 33,3 & 30,2 & 26,4 & 23,7 & 22,6 & 23,2 & 22,8 \\
\hline $\begin{array}{l}\text { Merkezi } \\
\text { Yönetim } \\
\text { Bütçe } \\
\text { Gelirleri }\end{array}$ & 22,4 & 23,8 & 22,1 & 21,6 & 21,3 & 22,7 & 22,0 & 21,6 & 21,1 \\
\hline $\begin{array}{l}\text { Bütçe } \\
\text { Dengesi }\end{array}$ & $-7,7$ & $-11,6$ & $-11,2$ & $-8,6$ & $-5,0$ & $-1,0$ & $-0,6$ & $-1,6$ & $-1,8$ \\
\hline $\begin{array}{l}\text { Faiz Dışı } \\
\text { Bütçe } \\
\text { Dengesi }\end{array}$ & 4,3 & 5,1 & 3,2 & 3,9 & 4,7 & 5,8 & 5,2 & 4,0 & 3,3 \\
\hline
\end{tabular}

Kaynak: (Hazine ve Maliye Bakanlığı) https://www.hmb.gov.tr/bumko-butce-buyuklukleri-vebutce-gerceklesmeleri (10.07.2019).

Yine tablo 2'den görüldügü üzere $\mathrm{AB}$ tanımlı genel yönetim borç stokunun GSYH'ye oranı 2004-2008 yılları arasında Maastricht Kriteri hedefi oranı olan yüzde 60 'ın altında kalmıştır.

Tablo 3: Türkiye'nin 2001-2008 Yıllar Arası Borç Stoku Göstergeleri (Milyon TL)

\begin{tabular}{|l|l|l|l|l|l|l|l|l|}
\cline { 2 - 8 } \multicolumn{1}{l|}{} & $\mathbf{2 0 0 1}$ & $\mathbf{2 0 0 2}$ & $\mathbf{2 0 0 3}$ & $\mathbf{2 0 0 4}$ & $\mathbf{2 0 0 5}$ & $\mathbf{2 0 0 6}$ & $\mathbf{2 0 0 7}$ & $\mathbf{2 0 0 8}$ \\
\hline $\begin{array}{l}\text { A.Genel } \\
\text { Yönetim } \\
\text { Toplam Borç } \\
\text { Stoku }\end{array}$ & 186.979 & 255.303 & 299.035 & 334.167 & 348.295 & 362.065 & 350.723 & 402.307 \\
\hline $\begin{array}{l}\text { B.İç Borç } \\
\text { Stoku }\end{array}$ & 128.531 & 159.509 & 208.292 & 240.177 & 260.020 & 266.989 & 271.087 & 293.815 \\
\hline $\begin{array}{l}\text { C.Dış Borç } \\
\text { Stoku }\end{array}$ & 58.449 & 95.794 & 90.743 & 93.990 & 88.275 & 95.076 & 79.636 & 108.491 \\
\hline $\begin{array}{l}\text { D.Ayarlama } \\
\text { Kalemleri }\end{array}$ & -271 & 3.643 & 8.631 & -1.013 & -6.295 & -9.432 & -14.666 & -22.800 \\
\hline $\begin{array}{l}\text { AB Tanıml } \\
\text { Genel } \\
\text { Yönetim Borç } \\
\text { Stoku (A+D) }\end{array}$ & 186.709 & 258.946 & 307.666 & 33.153 & 342.000 & 352.633 & 336.057 & 379.506 \\
\hline $\begin{array}{l}\text { AB Tanımlı } \\
\text { Genel } \\
\text { Yönetim } \\
\text { Nominal Borç } \\
\text { Stoku/GSYH } \\
\text { (\%) }\end{array}$ & 76,1 & 72,1 & 65,7 & 57,7 & 50,8 & 44,7 & 38,2 & 38,1 \\
\hline
\end{tabular}

Kaynak: (Hazine ve Maliye Bakanlığı) https://www.hmb.gov.tr/bumko-ekonomik-gostergeler (10.07.2019). 
Kamu maliyesinde yaşanan bu değişiklikler ekseninde 2003 yılında kabul edilen ve 2006 yılında tüm kamu kurumlarında uygulanan 5018 sayılı Kamu Mali Yönetimi ve Kontrol Kanunu ile kamu yönetiminde mali saydamlık ve hesap verme sorumluluğu kuralı getirilmiştir. Mali saydamlık, hükümetin yapısının, gerçekleştirdiği işlemlerin, mali politika planlarının, kamunun hesaplarının ve bütçe kanunu ile belirlenmiş hedeflerinin kamuya açı olmasıdır (Dede, 2010:92). Hesap verebilirlik ise, devletin kaynakları hukuka uygun ve etkin bir şekilde kullanmasını ve bu uygulamasının sorumluluğunun almasını ifade etmektedir.

$\mathrm{Bu}$ kapsamda, merkezi yönetim bütçe kanunu hazırlama sürecinin başlamasına sebep olan ve içeriğinde ülkenin uygulayacağı makro politikalar, ilkeler ve temel ekonomik büyüklükleri kapsayan Orta Vadeli Program (OVP) ile bütçe tahminlerini içeren ve kamu kurumlarının ödenek teklif tavanlarını içeren Orta Vadeli Mali Plan (OVMP), üç yıllık bir periyodu kapsayacak şekilde, her y1l hazırlanmak üzere 2005 yılından itibaren uygulanmaya başlamıştır. Kanunda bütçelerin nasıl hazırlanacağının gösterildiği bölümde "Orta Vadeli Program, Mali Plan ve Bütçe Hazırlama Rehberi” başlığı altında yer alan açıklamada (5018 Say1lı Kanun 16. Maddesi); "Merkezi yönetim bütçesinin hazırlanma sürecinin, Cumhurbaşkanı tarafindan en geç Eylül ayının ilk haftası sonuna kadar kalkınma planlarl, stratejik planlar ve genel ekonomik koşulların gerekleri doğrultusunda makro politikalarl, ilkeleri, hedef ve gösterge niteliğindeki temel ekonomik büyüklükleri de kapsayacak şekilde" Hazine ve Maliye Bakanlığınca hazırlanan ve Cumhurbaşkanınca onaylanan orta vadeli programın Resmi Gazete'de yayımlanması ile başlayacağı hüküm altına alınmıştır.

2006 yılında getirilen çok y1llı bütçeleme kamuda mali disiplini gerçekleştirerek siyasi karar alma ve kamu kaynaklarının etkin kullanılmasında önemli rol oynamaktadır. Kanunla ayrıca Stratejik Planlamaya Dayalı Performans Esaslı Bütçelemeyle analitik bütçeleme ve çok yıllı bütçelemeden yararlanılmaktadır. Bu kapsamda kanunun getirdiği yeniliklerden bir diğeri iç denetim ve iç kontrol mekanizmalarının aktif hale gelmesidir. Böylece kendisine yetki verilenlerin hesap verme sorumluluğundan dolayı, kamu kaynaklarını etkin ve verimli kullanıp kullanmadığı konusunda performans ölçümü yapılarak değerlendirme yapılmaktadır. Yine aynı kanunun uygulamaya girmesiyle "konsolide bütçe" uygulamasından "merkezi yönetim bütçesi" uygulamasına geçilmiş, merkezi yönetim içerisinde bulunan fakat daha önceki uygulamalarda bütçe dışında kaynak kullanan kamu kurumları bütçeye dahil edilmiş; bununla birlikte düzenleyici ve denetleyici kurumların gelir ve harcamaları da bütçeye dahil edilmiştir (Civriz, 2010:363). Bu sayede, kamu kesiminin yeni sınıflandırması çerçevesinde tüm kamu idarelerinin gelir ve giderleri bütçe içinde tek bir çatı altında toplanmıştır. Bu yapısal düzenlemeler ile birlikte mali yapı daha da sağlam hale gelmiştir. Yukarıda sayılan ilkelere paralel olarak, 5018 sayılı kanun ile kamu kurumlarının uyması gereken yeni kısıtlar belirlenmiştir. Söz konusu kısıtlar; harcama, kamu kurumları arasında ödenek aktarma, yedek ödenek kullanma, örtülü ödenek kullanma, ertesi yıla aktarılan yüklenme ve bütçe dışı avans kısıtlarıdır. 
Bunlardan başka 5393 sayılı Belediye Kanunu, 5216 sayılı Büyükşehir Belediyesi Kanunu ve 5302 say1lı İl Özel İdaresi Kanunu'na göre, belediyeler, büyükşehir belediyeleri ve il özel idareleri, sadece yatırım programlarında yer alan projelerinin finansmanı amacıyla dış borçlanma yapabilmesi ve yine belediyeler, il özel idareleri ve bunların bağlı kuruluşları ile sermayesinin \%50'sinden fazlasına sahip oldukları şirketlerin faiz dahil iç ve dış borç stok tutarının, en son kesinleşmiş bütçe gelirleri toplamının 213 sayılı Vergi Usul Kanununda belirlenen yeniden değerleme oranıyla artırılan miktarı ile sinırlandırılması mali kural niteliğindedir (Karakurt ve Akdemir, 2010:335). Bu kanunlar sadece yerel yönetimlerin borçlanmasını düzenlememiş aynı zamanda Hazine'nin ilgili yıl bütçe kanununda tahmin edilen bütçe açığı kadar net borçlanma yapabilmesi hükmünü de getirmiştir. Aynı zamanda bütçede yer almayan fakat yapılması gereken bir harcamayı karşılamak amacıyla çıkarılan tahvil anlamına gelen bütçe dışı ikraza da sınırlama getirilmesi öngörülmüştür. Kanunla getirilen bir diğer düzenleme de kamu kuruluşlarının dış projeleri için kullanacakları yatırım ödeneğinin önceden bütçeye konulması koşuludur (Dede, 2010:101). Kamu Mali yönetimi ve Kontrol Kanunu'nun getirdiği bu yeniliklerin yanında ayrıca 2000-2001 krizinin ardından kurulan Bankacılık Düzenleme ve Denetleme Kurulu (BDDK) ve Tasarruf Mevduatı Sigorta Fonu (TMSF) gibi düzenleyici ve denetleyici kurumlar aracılığgyla özellikle finansal kesimde kurallar konulmaya başlanmış ve bu kurumlar finansal piyasaların düzenlenmesinde önemli rol oynamışlardır (Şengönül ve Songur, 2010:2). 2001 yılında Merkez Bankası'nın hazineye kısa vadeli avans vermesi kaldırılmıştır. Yine bankanın bağımsızlığı artırılmış, şeffaflık ve hesap verilebilirlik çerçevesinde bankanın kamuoyuna ve parlamentoya raporlar sunarak düzenli bilgi vermesi sağlanmıştır.

Yukarıda sayılanların bazıları örtük mali kurallar, bazıları ise mali kuralları destekleyen uygulamalar olarak ülkemizde bugüne kadar uygulanmıştır. Erken seçimin yaşandığı 2007 yılından sonra IMF ile yeni bir anlaşma yapılmaması ve peşi sıra yaşanan küresel finansal krizin kamu borç stoğu ve kamu açıklarındaki olumsuz etkisi, halkta kural bazlı maliye politikasına geçiş beklentisini arttırmıştır (Dede, 2010:92).

2008 küresel finans krizinden sonrasını ele aldığımız bütçe dengesi göstergelerine ait olan tablo 3'de görüldüğü üzere krizden hemen sonraki y1llar olan 2009 ve 2010 yılında bütçe açığının GSYİH'ye oranı oldukça artmıştır. Oran sonraki yıllarda azalmıştır. Ancak krizden sonra dikkati çeken en önemli husus faiz dışı bütçe dengesinin krizden sonraki yıl yüzde 3,3 düşerek yüzde sıfira gerilemesi olmuştur ve bu oran günümüze kadar kriz önceki seviyesine ulaşamamıştır. 
Tablo 4: Türkiye’nin 2009-2020 (Tahmin) Y1llar Aras1 Bütçe Dengesi Göstergeleri (GSYIH'ye oran1)

\begin{tabular}{|l|l|l|l|l|l|l|l|l|l|l|l|l|}
\cline { 2 - 11 } \multicolumn{1}{c|}{} & $\mathbf{2 0 0 9}$ & $\mathbf{2 0 1 0}$ & $\mathbf{2 0 1 1}$ & $\mathbf{2 0 1 2}$ & $\mathbf{2 0 1 3}$ & $\mathbf{2 0 1 4}$ & $\mathbf{2 0 1 5}$ & $\mathbf{2 0 1 6}$ & $\mathbf{2 0 1 7}$ & $\mathbf{2 0 1 8}$ & $\begin{array}{l}\mathbf{2 0 1 9} \\
\text { Tahmin }\end{array}$ & $\begin{array}{l}\mathbf{2 0 2 0} \\
\text { Tahmin }\end{array}$ \\
\hline $\begin{array}{l}\text { Merkezi } \\
\text { Yönetim Bütçe } \\
\text { Giderleri }\end{array}$ & 26,8 & 25,4 & 22,6 & 23,1 & 21,9 & 21,9 & 21,6 & 22,4 & 22,3 & 22,1 & 21,7 & 21,1 \\
\hline $\begin{array}{l}\text { Merkezi } \\
\text { Yönetim Bütçe } \\
\text { Gelirleri }\end{array}$ & 21,6 & 21,9 & 21,3 & 21,2 & 21,5 & 20,8 & 20,6 & 21,2 & 20,8 & 20,2 & 19,8 & 19,5 \\
\hline Bütçe Dengesi & $-5,3$ & $-3,5$ & $-1,3$ & $-1,9$ & $-1,0$ & $-1,1$ & $-1,0$ & $-1,1$ & $-1,6$ & $-1,9$ & $-1,9$ & $-1,6$ \\
\hline $\begin{array}{l}\text { Faiz Dışı Bütçe } \\
\text { Dengesi }\end{array}$ & 0,0 & 0,7 & 1,8 & 1,2 & 1,7 & 1,3 & 1,3 & 0,8 & 0,3 & 0,2 & 0,3 & 0,6 \\
\hline
\end{tabular}

Kaynak: (Hazine ve Maliye Bakanlığı) https://www.hmb.gov.tr/bumko-butce-buyuklukleri-vebutce-gerceklesmeleri (10.07.2019).

Kriz sonrasında hazinenin daha kolay borçlanabilmesini sağlamak için 4749 sayılı Kamu Finansmanı ve Borç Yönetiminin Düzenlenmesi Hakkında Kanun'un 5'inci maddesinde değişikliğe gidilmiştir. Değişiklik öncesinde Hazine ilgili yıl bütçe kanununda öngörülen açıktan daha fazla net borçlanma yapamamakta iken (http://www.mahfiegilmez.com/2017/10/mali-kural-ve-cpa.html), 2009 y1lı bütçe açığının önemli ölçüde artmasıyla birlikte 5917 ve 5909 sayılı Kanunlarla yapılan değişikliklerle şunlar gerçekleştirilmiştir (Dede, 2010: 101);

- “...2009 yılı için, 1.1.2009 tarihinden geçerli olmak üzere Bakan ve Bakanlar Kurulu tarafından artırılan net borç kullanım tutarının beş katı uygulanır" hükmü getirilmiştir.

- Kredi garanti fonuna kaynak temin etmek için 1 milyar TL özel tertip DİBS ihraç edilmesi kararlaştırılmıştır. Aynı kanun ile Toprak Mahsülleri Genel Müdürlügünün 2009 yılı kampanya dönemi finansman açığını kapatmak için Hazine Müsteşarlığına ikrazen özel tertip DİBS ihraç etme yetkisi tanınmıştır.

Tablo 5: Türkiye'nin 2009-2017 Yıllar Arası Borç Stoku Göstergeleri (Milyon TL)

\begin{tabular}{|l|l|l|l|l|l|l|l|l|l|}
\hline & $\mathbf{2 0 0 9}$ & $\mathbf{2 0 1 0}$ & $\mathbf{2 0 1 1}$ & $\mathbf{2 0 1 2}$ & $\mathbf{2 0 1 3}$ & $\mathbf{2 0 1 4}$ & $\mathbf{2 0 1 5}$ & $\mathbf{2 0 1 6}$ & $\mathbf{2 0 1 7}$ \\
\hline $\begin{array}{l}\text { A.Genel } \\
\text { Yönetim } \\
\text { Toplam Borç } \\
\text { Stoku }\end{array}$ & 466.039 & 499.577 & 547.257 & 562.414 & 619.770 & 644.513 & 714.870 & 806.592 & 936.969 \\
\hline $\begin{array}{l}\text { B.İç Borç } \\
\text { Stoku }\end{array}$ & 350.812 & 373.850 & 390.982 & 410.218 & 429.606 & 440.233 & 469.532 & 505.768 & 584.498 \\
\hline $\begin{array}{l}\text { C.Dış Borç } \\
\text { Stoku }\end{array}$ & 115.227 & 125.727 & 156.275 & 152.197 & 190.164 & 204.280 & 245.337 & 300.824 & 352.471 \\
\hline $\begin{array}{l}\text { D.Ayarlama } \\
\text { Kalemleri }\end{array}$ & -27.828 & -34.612 & .38 .564 & -.48 .748 & -51.852 & -56.348 & -68.398 & -68.092 & -59.025 \\
\hline $\begin{array}{l}\text { AB Tanımlı } \\
\text { Genel } \\
\text { Yönetim } \\
\text { Borç Stoku } \\
\text { A+D) }\end{array}$ & 438.211 & 464.964 & 508.693 & 513.666 & 567.918 & 588.165 & 646.472 & 738.501 & 877.944 \\
\hline $\begin{array}{l}\text { AB Tanıml } \\
\text { Genel } \\
\text { Yönetim } \\
\text { Nominal } \\
\text { Borç } \\
\text { Stoku/GSYH } \\
\text { (\%) }\end{array}$ & 43,9 & 40,1 & 36,5 & 32,7 & 31,4 & 28,8 & 27,6 & 28,3 & 28,3 \\
\hline
\end{tabular}

Kaynak: (Hazine ve Maliye Bakanlığı) https://www.hmb.gov.tr/bumko-ekonomik-gostergeler (10.07.2019). 
Krizden sonra Maastricht kriteri olan borç stoğunun GSYIH'a oranının ilk iki yıl yükseldiği tablo 4'te görülmektedir. Takip eden yıllarda oranının düştüğü gözlemlenmektedir. Ancak bunun arkasında yatan en önemli sebep kamunun değil özel kesimin borç stoğunun artmasıdır.

Ülkemizde bu gelişmelerle birlikte, mali kural uygulanması 2009 ve 2010 yıllarında Orta Vadeli Program çerçevesinde gündeme gelmiş, "Mali Kural Kanun Tasarısı" hazırlanmıştır.

Tasarı bütçe açığına odaklanan bir mali kural benimsemiştir. Kanun Tasarısı'nda uygulamaya çerçeve oluşturacak temel ilkeleri aşağıdaki gibi belirtilmiştir (http://www2.tbmm.gov.tr/D23/1/1-0891.pdf, s:4. ):

$>$ Basitlik, doğruluk, saydamlık ve hesap verilebilirlik,

> Uygulama sonuçlarının tam ve zamanında kamuoyu ile paylaşı1ması,

$>$ Kanun kapsamındaki kuruluşların muhasebe ve raporlama işlemlerinin Avrupa Hesaplar Sistemi ve diğer uluslararası standartlarla uyumlu olarak yürütülmesi.

$>$ Kullanılan muhasebe ve istatistik yöntemlerinde önemli bir değişiklik yapıldığında bu hususun ivedilikle kamuoyu ile paylaşılması.

Söz konusu mali kuralın kapsamında; Genel Yönetim kapsamındaki idareler ve Kamu İktisadi Teşebbüsleri bulunmaktadır. Tasarıya göre mali kuralın uygulama sonuçları Maliye Bakanlığı'nca Mali Kural İzleme Raporu vasıtasıyla vatandaşlara duyurulacaktır. Mali Kural Kanun Tasarısı'nda Maliye Bakanlığının kuralı uygulamakla sorumlu olduğu, denetim biriminin ise Sayıştay Başkanlığ olduğu ifade edilmiştir. Meclis genel kurulunda görüşülmeden önce Mali Kural Yasa Tasarısı'ndaki bütçe açığı oranının yüzde 1'den yüzde 3'e çekilmesi talep edilirken, uygulama 2012 yılında yürürlüğe girmeden gündemden çıkartılmıştır.

Dünya genelinde mali kural uygulaması olarak en çok bütçe kuralı ve borç kuralı uygulanmaktadır. Bu husus aşağıdaki grafik 1'de de açıkça görülmektedir.

Grafik 1: 1985-2015 Yılları Arasında Dünya Genelinde Uygulanan Mali Kural Türleri ve Bu Kuralları Uygulayan Ülke Sayıları

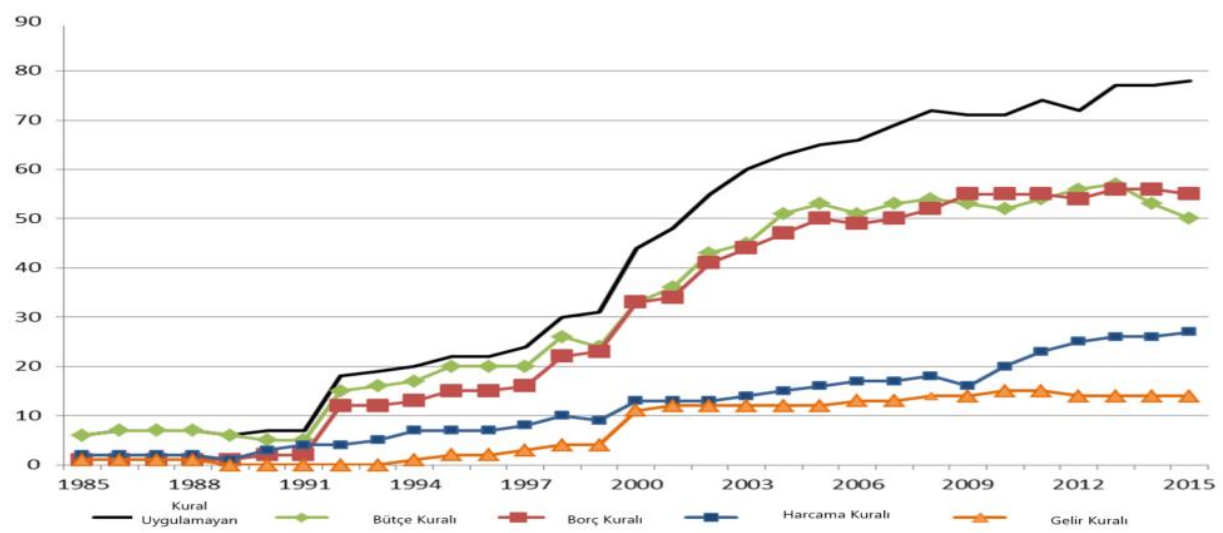

Kaynak: (Shmidt \& Soto, 2019:4). 
Ülkemizde de yasal anlamda mali kural uygulaması olmasa da örtük olarak uygulanan mali kurallar bütçe ve borç dengesine aittir. $\mathrm{Bu}$ anlamda ülkemiz dünya örnekleri paralelinde uygulama yapmaktadır. Fakat gerek tasarıda yer alan, gerekse de örtük olarak uygulanmakta olan bütçe ve borçlanma dengesine ait kriterlere uyum sağlansa da mali kuralın getiriliş amacı olan mali disiplinin gerçekleştirilmesi aynı zamanda bir gelir kuralının uygulanmasına da bağlıdır. Çünkü mali kuralların kalbi olan bütçe açığının belli bir seviyede tutulması ve hatta bütçe dengesinin sağlanması için sadece kamu harcamalarının azaltılması yetmemekte aynı zamanda yeterli gelir elde edilmesi gerekmektedir. Gelir artırımı ya vergi oranlarının yükseltilmesi ya da vergi tabanının genişletilmesiyle gerçekleşmektedir. Ülkemizde vergi oranlarının yeteri kadar yüksek olduğu düşünüldüğünde gelir elde etmenin tek yolu vergi tabanının genişletilmesi olarak görülmektedir. Ancak burada da büyük bir sorun karşımıza çıkmaktadır. Vergi tabanının genişletilmesi demek şu an mevcut kayıtdış1 faaliyetlerin kayıt altına alınması demektir. Kayıtdışı faaliyetler ise vergi oranlarının yüksekliğinden kaynaklanmaktadır. $\mathrm{Bu}$ sebeple ülkemizde vergi tarifeleri etkin bir şekilde tekrar düzenlenmelidir. Sistemdeki dolaylı vergi ağırlığ 1 azaltılmalı, vergi adaletini gerçekleştirmek için dolaysız vergilere ağırlık verilmelidir. Bunun gerçekleşmesi anayasamızın 73. maddesinde yer alan ve bu nedenle "gerçek bir mali kural" olan vergilemenin sosyal amacının da gerçekleştirilmesi anlamına gelmektedir.

Olası bir mali kural kanununun başarılı olabilmesi için yukarıda belirtilen adil vergi sisteminin yanı sıra, kamu harcamalarında israftan kaçınılmalı, mali alandaki aktörlerin kamu tercihi teorisinde belirtilen davranış zayıflıklarına yer vermeyecek şekilde hareket etmelerini sağlayacak mekanizma kamu yönetiminde gerçekleştirilmelidir (Günay, 2007:398). Ülkemizde hala uygulanan büyük boyutlu seçim ekonomisi mali kural uygulamasının teorik temellerini oluşturan normatif kamu tercihi teorisi mantığına aykırı düşmektedir. Bu nedenle siyasi alanın hem arz hem talep cephesindeki aktörlerin bilinç düzeylerinin yükseltilmesine yönelik kalkınma politikasına ağırlık verilmesi gerekmektedir. $\mathrm{Bu}$ insani gelişmişlik seviyesine ulaşılması aslında bir anlamda iktisat politikasının tüm amaçlarının da gerçekleşmesine sebep olacaktır.

\section{SONUÇ}

Mali kural uygulamaları, ekonominin iki ayağından biri olan ve aksayan kamu ekonomisi ayağının daha sağlam yere basması için uygulanan kurallardır. Ülke örneklerinde görüldüğ̈̈ gibi örtük ya da açık mali kural niteliğindeki uygulamalar ekonomide ortaya çıkan sorunları tam anlamıyla çözmese bile belli derecede etkili olmaktadır. Basiretli hükümetlerin mali kural uygulamasına gitmeden de başarılı oldukları bir gerçektir. Ancak siyasi - psikolojik ortam çerçevesinde bu başarı oranı oldukça düşük olmaktadır. Özellikle gelişmekte olan ülkelerin karmaşık yapısal sorunları ve beşeri sermayesinin niteliğinin gelişmiş ülkelere kıyasla düşük düzeyde olması, politik aktörlerin davranışlarının faydacı temelde gerçekleşmesine neden olmaktadır. Siyasetçilerin çıkarlarını gerçekleştirmek için kullandıkları politikalar israfa neden olmakta, israf ekonomik 
kırılganlığı arttırmaktadır. Ekonomik kırılganlık ise kırılganlığın yaşandığ1 dönemdeki vatandaşların yaşam standartlarını düşürdüğü gibi borçlanma ihtiyacını sürekli hale getirerek gelecek nesillerin üzerine de mali yük bindirmektedir.

Kamu Tercihi Teorisinin ortaya çıkmasındaki ana sebeplerin başında yer alan bu gerçekler, mali kuralların doğuşunu hazırlamıştır. Mali kuralın uygulanmas i ile ilgili dünyada bir standart yoktur. Ancak yasal olarak mali kural uygulayan ülkelerde bir takım kurallar bütünü yer almakta iken, ülkemiz gibi örtük mali kural uygulayan ülkelerde, mali kural uygulayan ülkeler örnek alınmakta, fakat bu kuralların bir kısmı yasal temel olmadan uygulanmaktadır.

Mali kuralların başarılı olması için kural oluşturan ülke, kuralları ilk önce kendi yapısal özelliklerini dikkate alarak oluşturmalıdır. Bu husus, mali kuralları iradi maliye politikaları karşısında güçsüz bırakan, kuralların esnek olmaması özelliğini büyük ölçüde ortadan kaldıracaktır. Kuralların oluşum aşamasında, nominal büyüklükler mi yoksa belli ekonomik göstergelerin oranları olarak mı belirleneceği konusuna dikkatli yaklaşmak gerekmektedir. Kuralların oran olarak belirlenmesi esneklik özelliğini kuvvetlendirici uygulamalar olacaktır. Son olarak değinilmesi gereken nokta nicel mali kuralların belirlenmesinden önce mutlaka kuralların altyapısının oluşturulması gerektiğidir. Altyapı, kural uygulamalarını güçlendirmektedir. Burada altyapı olarak kastedilen bütçe reformlarıdır. Bütçe reformları ise çok y1llı bütçeleme, çok kapsamlı bütçeleme, gerçek anlamda uygulanan hesap verilebilirlik ve şeffaflıktır.

Ülkemizde 2003 yılında kabul edilen, 2006 y1lında tüm kamu kurumlarında uygulanmaya başlanan 5018 sayılı kanunla, çalışmamızın daha önceki kısımlarında belirtilen mali kurallar için yasal ve kurumsal altyap1 gerekliliği büyük ölçüde yerine getirilmiştir. Çok yıllı bütçeleme, bütçenin kapsamın genişletilmesi, fonların sayısının azaltılması, performansa dayalı bütçeleme sistemi gibi uygulamalar denk bütçe kuralının ve uygulanmasının bir anlam ifade etmesi açısından önemlidir. Ancak bütçe uygulamalarının mali saydamlık ve hesap verilebilirlik çerçevesinde etkin denetiminin yapılması gerekmektedir. Yapılacak denetimler belirli yaptırımlarla tamamlanmalıdır ki bu durum mali kural uygulamasının en önemli eksikliklerindendir.

Bununla birlikte bütçe açıklarının azalmasını sağlayacak bir diğer önemli unsur kamu borç stoğunun azaltılması gerekliliğidir. Nitekim bu husus AB'de ayrı bir mali kuraldır. Ülkemiz kalkınma yolunda ilerlerken en gerekli olan yatırım harcamalarının rahatlıkla gerçekleştirilebilmesi için, sadece yatırımlar için uygulanacak borçlanmayı ifade eden "altın kural" uygulaması yürürlüğe girmelidir.

Bütçe disiplininin sağlanmasının bir ayağını da gelir artırıcı politikaların oluşturduğu göz önüne alınırsa gelir arttırmak için anayasamızda da belirtildiği üzere vergi yükünün adaletli ve dengeli dağllımın gerçekleştirilmesi, bu anlamda dolaylı ve dolaysız vergi ağırlığının düzeltilmesi ve verginin adil bir şekilde tabana yayılması gerekmektedir. Verginin tabana yayılması için gerekli olan başka bir unsur etkin vergi denetimidir. Ülkemiz uygulamasına bakıldığında 
denetlenme ihtimalinin düşük olduğunu bilen mükelleflerin, aynı zamanda mali af beklentilerinden dolayı da vergi ahlakı gelişmemektedir.

Dünya genelindeki uygulamalara bakıldığında gelir kurallarının en az uygulanan mali kural türü olduğu görülmektedir. Dünya, ağırlıklı olarak borç kuralı ve bütçe açığı kuralına odaklanmıştır. Özellikle AB'deki Maastiricht Kriterleri bunun en güzel örneğidir.

ABD ve Japonya'da da 1990'lı yıllarda bütçe açığı ve kamu borcunu azaltmak için faiz dışı fazla verme kuralı uygulanmış, belirli dönemlerde başarı sağlansa da bu konuda istikrar sağlanamamıştır. Özellikle küresel krizden sonra dünya genelinde bütçe açığı ve borç stoğu göstergelerinde bozulmalar gerçekleşmiştir. Küresel krizden sonra belirli ülkelerde mali kural uygulamaları sonlandırılmış, diğerlerinde ise revizyona gidilmiştir.

\section{KAYNAKÇA}

26 Mayıs 2010 Tarihli Mali Kural Kanun Tasarısı (2010). erişim http://www2.tbmm.gov.tr/D23/1/1-0891.pdf.

24 Aralı 2003 Tarihli 5018 Sayılı Kamu Mali Yönetimi ve Kontrol Kanunu (2003). erişim. www.mevzuat.gov.tr/MevzuatMetin/1.5.5018.doc

Aktan, C.C. (2003). Kamu Ekonomisi ve Kamu Maliyesi. İzmir: Birleşilik Matbbacıllk.

Aktan, C.C., Dileyici, D. \& Vural İ.Y. (2006). Kamu Ekonomisi ve Kamu Politikası. Ankara: Seçkin Yayıncilık.

Binay, Ş.(2003). Some Issues in Fiscal Policy and Central Banking: The Case of Turkey. erişim https://www.bis.org/publ/bppdf/bispap20y.pdf

Büyükkaya, A. (2010). Mali Kural Ne Getirecek, Capital Geniş Açı Dergisi, Geniş Açı Eki.

CIVRIZ, M. (2010). Türkiye’de Mali Disiplini Sağlamaya Yönelik Mali Hükümler Ve Mali Kural Benzeri Uygulamalar. Aktan, C.C., Kesik, A. \& Kaya, F. (Ed.), Mali Kurallar Maliye Politikası Yönetiminde Yeni Bir Eğilim: Vergi, Harcama, Borçlanma vs. Üzerine Kurallar ve Sinırlamalar (s. 347-379). Ankara: Maliye Bakanlığ Strateji Geliştirme Başkanlığı.

Creel, J. \& Saraceno, F. (2010). European Fiscal Rules After The Crisis. De Boeck Supérieur, 108. Erişim https://www.cairn.info/revue-journal-of-innovation-economics-2010-2-page95.htm

Çelebi, A.K. (2015). Liberal Ekonomik Düşüncede Kamu Kesiminin Büyüklüğ̈̈ Sorunu. Manisa: Emek Matbaasl

Dede, M.M. (2010). Anayasal İktisat Perspektifinden Maliye Politikası Kuralları Ve Avrupa Birliği Ülkelerinde Uygulamanın İncelenmesi. Ankara: Maliye Bakanlı̆̆ Strateji Geliştirme Daire Başkanlığı.

Günay, A. (2007). Mali Disiplinin Sağlanmasında Anayasal Denk Bütçe Yaklaşımı ve Türkiye'de Uygulanabilirliği. Ankara: Maliye Bakanlığ Strateji Geliştirme Başkanlı̆̆ .

Günaydın, İ., Eser, L.Y. (2009). Maliye Politikasında Yeni Trend: Mali Kurallar. Maliye Dergisi. $156,51-65$.

Güngör, K. (2016). 2008 Küresel Krizi Sonrası Yeniden Gündeme Gelen Mali Kural: Avrupa Birliği ve OECD Ülkeleri İçin Bir Değerlendirme. Afyon Kocatepe Üniversitesi Sosyal Bilimler Dergisi, 18(1), 173-198.

Hagen, J.V. (2005). Fiscal Rules and Fiscal Performance in the European Union and Japan. Institute For Monetary And Economic Studies Discussion Paper Series, E-5, 8-5. erişim http://www.imes.boj.or.jp/english/publication/edps/2005/05-E-05.pdf.

http://www.canaktan.org/ekonomi/anayasal_iktisat/buchanan-life-legacy/turkcekaynaklar/buchanan-pur-maliye.htm

http://www.canaktan.org/ekonomi/anayasal_iktisat/kamu-tercihi.htm

http://www.mahfiegilmez.com/2017/10/mali-kural-ve-cpa.html 
https://ec.europa.eu/info/business-economy-euro/economic-and-fiscal-policy-coordination/eueconomic-governance-monitoring-prevention-correction/stability-and-growthpact/history-stability-and-growth-pact_en\#2014

https://www.hmb.gov.tr/bumko-butce-buyuklukleri-ve-butce-gerceklesmeleri

https://www.hmb.gov.tr/bumko-ekonomik-gostergeler

IMF. (2009). Fiscal Rules- Anchoring Expectations for Sustainable Public Finances. erişim https://www.imf.org/external/np/pp/eng/2009/121609.pdf

IMF. (2018). Fiscal Policy-How to Select Fiscal Rules-A Primer.Washington DC:Fiscal Affairs Department.

www.imf.org/ /media/Files/Publications/HowToNotes/HowToNote1809.ashx,

Karakurt, B. \& Akdemir, T. (2010). Türkiye'de Mali Kural Uygulamaları: Saylsal Olmayan Kurallardan Sayısal Kurallara Geçiş. Aktan, C.C., Kesik, A \& Kaya, F. (Ed.), Mali Kurallar-Maliye Politikası Yönetiminde Yeni Bir Eğilim: Vergi, Harcama, Borçlanma vs. Üzerine Kurallar ve Sinırlamalar (320-346). Ankara: Maliye Bakanlığl Strateji Gelişstirme Başkanlığ

Karayazı, M. (2017). Küresel Krizin Mali Kural Uygulamalarına Etkisi: Seçilmiş Ülke Örnekleri Açısından Bir İnceleme. Uluslararası Sosyal Araştırmalar Dergisi, 10(51), 1047-1058.

Kaya, F. (2009). Mali Kural Uygulamalarl ve Türkiye İncelemesi. DPT Uzmanlı Tezi, Ankara.

Lledó, V., Yoon, S., Fang, X., Mbaye, S. \& Kim, Y. (2017). Fiscal Rules at a Glance, International Monetary Fund. erişim https://www.imf.org/external/datamapper/fiscalrules/Fiscal\%20Rules\%20at\%20a\%20Gla nce\%20-\%20Background\%20Paper.pdf .

Honjo, K. (2007). The Golden Rule and the Economic Cycles. IMF Working Paper. 07/99. erişim https://www.imf.org/external/pubs/ft/wp/2007/wp07199.pdf.

Miynat, M \& Bostan, M.K. (2015). Mali Kural Uygulamalarının Makroekonomik Değişkenler Üzerine Etkileri. Yönetim ve Ekonomi, 22(2), 535-549.

Özlale, Ü. (2010). Mali Kural, Keşke Sadece Denklem Olsaydl. Ankara: TEPAV.

Sakal, M. \& Şahin, E. A. (2009). Anayasal İktisadın Temel Felsefesi ve Türkiye'de Uygulanabilirlik Koşulları. Eskişehir Osmangazi Üniversitesi Sosyal Bilimler Dergisi, 10(1), 75-114.

Samsar, A. (2003). Optimal Para Alanı Teorisi Çerçevesinde Türkiye Analizi, Uzmanlık Yeterlilik Tezi. Ankara: TCMB Ístatistik Genel Müdürlü̆̈̈̈.

Saygılığlu, N. \& Erduran, A.Ç. (2012). Mali Kural ve Etkinlik Sorunu: Türkiye Örneği. TiSK Akademi, 1, 18-52.

Schaechter, A., Kinda, T., Budina, N. \& Weber, A. (2012). Fiscal Rules in Response to the CrisisToward the "Next-Generation" Rules. IMF Working Paper.

Schmidt, K. \& Soto H.R. (2019). Fiscal Rules and Fiscal Performance: World Evidence. WEAI 15th International Conference Keio University, Tokyo.

Sevgi, H. (2018). Mali Kural Kavramı ve Politika Çerçevesi. Fiscaoeconomia, 2(1), 154-185.

Sönmez, S. (2011). Küresel Finansal Kriz Ortamında Maliye Politikası ve Mali Kural. İktisat ve Toplum, 1(7), 18-23.

Şen, H. \& Kaya, A. (2015). Ekonomik Krizlerin Değişmeyen İmdatçısı: Maliye Politikası. Sosyoekonomi, 1, 55-86.

Şen, K. (2010). Mali Kural, Bazı Uluslararası Uygulamalar ve Türkiye İncelemesi. Bütçe Dünyası Dergisi, 34(2), 26-57.

Şengönül, A. \& Songur, M. (2010). Türkiye'de Mali Kural: Olsaydı Ya Da Olacaksa, Ankara: SETA. Şevik, E. (2008). Mali Kurallar. Bütçe Dünyası Dergisi, 3(28), 50-59.

Utkulu, U. (2005). Avrupa Parasal Birliği Gerçekten Bir Optimum Para Sahası mıdır?. ESİAD, 1(1).

\section{SUMMARY}

The government, which is an indispensable element of the life of the society, carries out public service to its citizens, who have established itself through constitutions, and practices within the framework of certain legal institutional arrangements. One of these legal arrangements is the budget law. The 
numerical limit of the services to be provided by governments in a given period is defined in budget laws. Because the budgets also indicate the source of financing and the amount of this source, which is the equivalent of public expenditure to be made for public services.

In particular, the party in power and the bureaucracy working in line with the government program of the party in power have to use the budgetary resources in the public interest. However, governmental exepriences throughout the history has clearly shown that these political actors deviate from the public interest and act in their own interest. This fact led to the emergence of a school of economics called "Public Choice Theory" which re-interrogated the structure of the government. The positive approach of the Public Choice theory led by James M. Buchanan identified the underlying causes of individual behavior in political life as "methodological individualism" and "political exchange". Accordingly, every individual who active in the political field pursues his own interests, just like in the market, and enters into an exchange to obtain these interests. As a result of this, public resources are wasted. In line with this fact, the normative approach of Public Choice Theory has listed what should be. Accordingly, the most important fact that should be in the political field is that the economy should also have a constitution. This is how the "Constitutional Economics" theory emerged. In theory, the term "economic constitution" refers the rule of public expenditures, revenues and debts. This proposal of the theory has taken its place in practice as "fiscal rule".

Although fiscal rule practices date back to old times, their legal foundations were laid in the United States in the 1990s. Later on, it took its place as "Maastricht Criteria" in the European Union within the framework of fiscal discipline applications. Today, these criteria are binding for both member and candidate countries. Fiscal rule applications have found places in not only the West but also in most of the countries around the world. Japan, one of the leading countries in Asia, is one of these countries. Although the rules applied differently in different countries have succeeded in achieving fiscal discipline, there have been difficulties in adapting to extraordinary situations in practice, a number of countries even abandoned the implementation of fiscal rules.

Although there are rules similar to the fiscal rule in Turkey, unfortunately a rule, which is exactly named "fiscal rule" has not been established yet. Existing practices from past to present have been carried out with the responsibility of being a social state and providing financial discipline. If the rules which falling on the World agenda again after the global crisis, will be applicable in our country, especially the procedural infrastructure shoul be prepared very well, the scope should be expanded to include public revenues, the flexibility to adapt to extraordinary situations should be added to the system and certain sanctions should be attached within the framework of accountability. 